\title{
Stigma Masyarakat terhadap Penderita Covid-19
}

\section{Community Stigma for Covid-19 Sufferers}

\author{
Syntha Novita ${ }^{1}$, Yunus Elon ${ }^{2}$ \\ Fakultas Ilmu Keperawatan, Universitas Advent Indonesia, Indonesia
}

\section{ARTICLE INFO}

\section{Article history}

Received date 02 Mar 2021

Revised date

03 Mar 21

21 Mar 21

Accepted date

08 Apr 2021

\section{Keywords:}

Covid-19;

Public Acceptance;

Stigma.

\section{Kata kunci:}

Covid-19;

Penerimaan Masyarakat; Stigma.

\author{
ABSTRACT/ ABSTRAK
}

Covid-19 is a deadly disease that infects the respiratory system and can spread very quickly. The number of covid-19 cases that are increasing every day creates pressure on the community, which triggers the stigmatization of covid-19 sufferers. This study aims to analyze the stigma picture of society and see the relationship between stigma and public acceptance of covid-19 sufferers. This type of descriptive-analytic research with a quantitative approach. The subjects were 300 students studying at the Bandung city university who were selected using a non-probability technique with an incidental sampling approach. The instrument used was adopted and modified from the existing public acceptance questionnaire and tested the validity and reliability of 30 subjects with $r$ table>,361 with a significance level of 5\%, with a Cronbach alpha reliability ,794. The results of the univariate analysis showed that instrumental stigma was categorized as low 99 (33\%), high $201(67 \%)$, low symbolic stigma 134 (44,7\%), high $166(55,3 \%)$, low politeness stigma $241(80,3 \%)$ ), high $59(19,7 \%)$ and good public acceptance of 225 (75\%) and poor $75(25 \%)$. The results of the chi-square analysis showed a significant relationship with instrumental, symbolic, and modesty stigma towards public acceptance. The higher the instrumental stigma and symbolic stigma in society, the worse the public's acceptance of covid-19. Education regarding the prevention and spread of covid-19 and the importance of mental health during the covid-19 pandemic needs to be improved so that the public is not misinformed and the perceptions about covid-19.
Covid-19 adalah penyakit mematikan yang menginfeksi sistem pernapasan dan dapat menular dengan sangat cepat. Angka kasus Covid-19 yang semakin bertambah setiap hari menimbulkan tekanan bagi masyarakat sehingga memicu adanya stigmatisasi terhadap penderita Covid-19. Penelitian bertujuan untuk menganalisis gambaran stigma masyarakat dan melihat hubungan antara stigma dan penerimaan masyarakat terhadap penderita Covid-19. Jenis penelitian deskriptif analitik dengan pendekatan kuantitatif. Subyek berjumlah 300 mahasiswa yang berkuliah di Perguruan Tinggi Kota Bandung yang dipilih dengan menggunakan teknik non probability dengan pendekatan incidental sampling. Instrumen yang digunakan diadopsi dan dimodifikasi dari kuesioner penerimaan masyarakat yang sudah ada dan dilakukan uji validitas dan reabilitas terhadap 30 subyek dengan r-tabel >,361 taraf signifikansi 5\%, dengan reliability alpha cronbach ,794. Hasil analisis univariate menunjukkan Stigma Instrumental kategori rendah 99 (33\%), tinggi 201 (67\%), Stigma Simbolis rendah 134 (44,7\%), tinggi 166 (55,3\%), Stigma Kesopanan rendah 241 (80,3\%), tinggi 59 (19,7\%) dan Penerimaan Masyarakat baik 225 (75\%) dan buruk 75 (25\%). Hasil analisis chi-square menunjukkan hubungan yang signifikan stigma instrumental, simbolis dan kesopanan terhadap penerimaan masyarakat. Semakin tinggi stigma instrumental dan stigma simbolis di masyarakat maka semakin buruk penerimaan masyarakat terhadap Covid-19. Edukasi mengenai pencegahan dan penyebaran Covid-19 serta pentingnya kesehatan mental selama pandemi Covid-19 perlu ditingkatkan agar masyarakat tidak salah informasi dan persepsi mengenai Covid-19.

\section{Corresponding Author:}

\section{Syntha Novita}

Fakultas Ilmu Keperawatan, Universitas Advent Indonesia, Indonesia

Email: novitasyntha@gmail.com

\section{PENDAHULUAN}

Covid-19 merupakan penyakit yang disebabkan oleh virus corona yang menginfeksi sistem pernapasan sehingga menyebabkan gagal napas. Virus ini pertama kali ditemukan tahun 2019 di Cina Tengah tepatnya di kota Wuhan, yang teridentifikasi pada makanan laut dengan 
nama coronavirus disease atau Covid-19 (Abdillah, 2020). Menurut WHO, Per 1 November 2020, hampir 46 juta kasus dan 1,2 juta kematian secara global. Dimana Amerika Serikat, India, dan Perancis menempati posisi teratas dengan kasus tertinggi dalam empat minggu terakhir (World Health Organization, 2020).

Sementara itu, data perkembangan Covid19 Indonesia update hingga tanggal 6 November 2020 Pukul 08.00 WIB (KEMKES RI, 2020) adalah 425.796 kasus konfirmasi, 14.348 kasus meninggal $(3,4 \%), \quad 357.142$ kasus sembuh $(83,9 \%), 54.306$ kasus aktif (12,8\%). Begitu pula yang terjadi di Provinsi Jawa Barat khususnya di kota Bandung, hingga tanggal 6 November 2020 Pukul 23.25, total kasus terkonfirmasi adalah 2.150, diantaranya konfirmasi aktif sebanyak 199, konfirmasi sembuh sebanyak 1.860, konfirmasi meninggal 91 (PUSICOV Kota Bandung, 2020).

Angka kasus Covid-19 yang terus bertambah setiap hari berpengaruh besar pada kesehatan mental masyarakat (Ilpaj \& Nurwati, 2020). Studi penelitian yang dilakukan di Cina pada bulan Januari dan Februari 2020 menunjukkan bahwa 53,8\% mengalami dampak psikologis berat, $16,5 \%$ melaporkan gejala depresi sedang hingga berat, 28,8\% melaporkan gejala kecemasan sedang hingga berat, $8,1 \%$ melaporkan tingkat stres sedang hingga berat, dan $>70 \%$ khawatir anggota keluarga mereka tertular Covid-19 (Wang, et al., 2020). Dampak pandemi Covid-19 juga menyebabkan orang harus menjalani seluruh aktifitasnya di dalam rumah, sehingga menimbulkan kebosanan dan kejenuhan yang berujung pada gejala stres (Muslim, 2020). Ditambah dengan penyebaran berita hoax di berita dan sosial media. Whatsapp dan Facebook merupakan media yang paling sering menyebarkan disinformasi sehingga menimbulkan kebingungan di tengah masyarakat (Bafadhal \& Santoso, 2020). Penyebab lainnya dikarenakan ketakutan akan kehilangan pekerjaan selama masa pandemi Covid-19 (Setyaningrum \& Yanuarita, 2020)..

Penelitian yang dilakukan pada remaja usia 12-19 tahun ditemukan kecemasan kategori tinggi pada masa pandemik Covid-19 (Fitria \& Ifdil, 2020). Dampak pandemi terhadap dunia pendidikan juga dirasakan oleh pelajar dan staf pengajar di Indonesia, yaitu dilakukannya pembelajaran melalui daring. Beberapa pengalaman negatif diantaranya, kurang adanya kerjasama antar pelajar, menurunnya motivasi belajar, standar pembelajaran cenderung lebih rendah dibandingkan saat offline, materi yang dipaparkan kurang dapat dimengerti, kurang fokus saat kegiatan belajar mengajar, dan kurang interaktif (Gultom \& Tambunan, 2021).

Peningkatan stres juga dialami oleh petugas kesehatan yang disebabkan karena tingginya risiko penularan virus dalam melakukan pekerjaan sehari-hari (Grover, et al., 2020). Kondisi psikologis tenaga kesehatan selama pandemi Covid-19 menunjukkan gejala stres karena beban kerja, stigma, dan kekhawatiran terinfeksi Covid-19 (Handayani, et al., 2020). Masalah kesehatan mental yang dialami oleh petugas medis bukan hanya berpengaruh pada kualitas pelayanan dan pengambilan keputusan yang bisa menghambat upaya dalam menangani Covid-19, tapi secara khusus berdampak pada kesejahteraan individu secara menyeluruh (Ridlo, 2020).

Ketakutan, kecemasan, dan banyaknya informasi melalui media sosial, yang tidak semuanya dapat dipercaya, telah menimbulkan stereotip negatif bagi orang-orang yang terkait dengan Covid-19, baik pasien Covid-19, suspek Covid-19, eks pasien Covid-19, maupun petugas kesehatan yang menangani pasien Covid-19.

Di Indonesia, stigma muncul melalui beberapa perilaku seperti mengucilkan eks pasien Covid-19 dan penolakan jenazah karena dianggap bisa menularkan penyakitnya, mengucilkan etnis tertentu yang dianggap sebagai pembawa virus, serta mengucilkan tenaga kesehatan (Livana, et al., 2020). Lebih lanjut dikatakan dalam penelitian Liu, et al (2020) pada penduduk AS yaitu persepsi diskriminasi terkait Covid-19 meningkat dari $4 \%$ menjadi $10 \%$. Stigma dapat mengganggu upaya pemutusan rantai virus. Orang yang merasa khawatir akan dijauhi dan diperlakukan buruk akan menghindari pengobatan (Satuan Tugas Penanganan Covid-19, 2020).

Didukung oleh penjelasan WHO (2020) yang mengatakan bahwa stigma dapat mendorong orang menyembunyikan penyakitnya, mencegah orang mencari perawatan kesehatan, dan mencegah orang untuk mengadopsi perilaku sehat. Beberapa kasus menunjukkan ketidakjujuran pasien mengenai riwayat penyakitnya serta riwayat perjalanan dan riwayat kontaknya ketika berobat ke layanan kesehatan. Akibatnya, beberapa dokter dan tenaga medis lainnya tertular Covid-19 dan bahkan meninggal dunia (CNN Indonesia, 2020). Penelitian mengenai gambaran stigma terhadap orang-orang terkait Covid-19 khususnya di Indonesia belum banyak dilakukan. Berdasarkan latar belakang diatas peneliti tertarik untuk mengetahui gambaran stigma masyarakat dan menganalisis 
hubungan antara stigma dan penerimaan masyarakat terhadap penderita Covid-19.

\section{METODE}

Penelitian ini merupakan jenis deskriptif analitik dengan pendekatan kuantitatif. Penelitian ini dilakukan di Kota Bandung dan dilaksanakan pada bulan Oktober 2020. Populasi dalam penelitian adalah masyarakat yang tinggal di Kota Bandung. Sampel diambil berdasarkan kriteria inklusi antara lain, mahasiswa/mahasiswi yang berkuliah di Perguruan Tinggi Kota Bandung, mereka yang mengalami gangguan mental, atau tidak memiliki kemampuan membaca tidak diikutsertakan dalam penelitian ini. Sebanyak 300 subyek dipilih dengan menggunakan teknik non probability dengan pendekatan accidental sampling. Instrumen yang digunakan untuk mengumpulkan data diadopsi dan dimodifikasi dari kuesioner penerimaan masyarakat yang sudah ada dan telah diuji nilai validitas dan reabilitasnya. Sebanyak 30 orang bersedia untuk pilot study, item-item pertanyaan yang nilai r-tabelnya>,361 digunakan untuk penelitian selanjutnya. Hasil uji reliability alpha cronbach .794 yang diinterpretasikan reliable atau konsisten.

Dalam penelitian ini yang menjadi variabel independen adalah stigma Covid-19 yaitu: stigma instrumental, stigma simbolis dan stigma kesopanan. Variabel dependen dalam penelitian ini adalah penerimaan masyarakat.

Stigma Instrumental Covid-19 diukur dengan 4 item pertanyaan mengenai pengetahuan masyarakat terhadap Covid-19, Stigma Simbolis Covid-19 diukur dengan 4 item pertanyaan mengenai sikap masyarakat terhadap penderita Covid-19, Stigma Kesopanan diukur dengan 6 item pertanyaan mengenai perilaku terhadap penderita Covid-19, Penerimaan Masyarakat diukur dengan 7 item pertanyaan mengenai pergaulan antara masyarakat dengan penderita Covid-19.

Penelitian ini telah mendapatkan persetujuan penelitian dari Dekan Fakultas Ilmu Keperawatan UNAI dengan nomor surat 147/EKS-SU/VII/20 dan sertifikat layak etik dengan nomor 096/KEPK-FIK.UNAI/EC/IX/20. Peneliti meminta izin responden yang akan diberi penjelasan tentang tujuan dari penelitian melalui aplikasi Whatsapp dan akan diminta untuk berpartisipasi secara sukarela dalam penelitian. Jika bersedia, maka responden akan diberikan informed consent dalam bentuk Google Form. Metode analisis data menggunakan analisis univariat dan bivariat sesuai dengan variabelnya.

HASIL

Tabel. 1. Distribusi Subjek Berdasarkan Jenis Kelamin, Usia, Pendidikan, Tingkat, dan Agama

\begin{tabular}{llrr}
\hline Variabel & Kategori & Frekuensi & \% \\
\hline \multirow{2}{*}{ Jenis Kelamin } & Laki-laki & 99 & 33 \\
& Perempuan & 201 & 67 \\
Usia & Remaja Awal & 296 & 98,7 \\
& Dewasa Awal & 4 & 1,3 \\
Pendidikan & Diploma & 38 & 12,7 \\
& Sarjana & 262 & 87,3 \\
& Satu & 52 & 17,3 \\
Tingkat & Dua & 46 & 15,3 \\
& Tiga & 144 & 48 \\
& Empat & 57 & 19 \\
& Protestan & 231 & 77 \\
Agama & Islam & 66 & 22 \\
& Budha & 1 & 3 \\
& Katholik & 2 & 7 \\
\hline
\end{tabular}

Tabel 1 menunjukkan subyek penelitian sebagian besar adalah perempuan yaitu 201 orang (67\%) dan laki-laki sebanyak 99 orang $(33 \%)$. Berdasarkan usia, sebanyak 296 orang $(98,7 \%)$ masuk dalam kategori remaja akhir dan sebanyak 4 orang $(1,3 \%)$ kategori dewasa awal. Dari segi pendidikan, sebanyak 262 orang (87,3\%) Sarjana dan 38 orang (12,7\%) Diploma. Untuk tingkat pendidikan, sebagian besar mahasiswa tingkat tiga sebanyak 144 orang (48\%), tingkat empat 57 orang (19\%), tingkat satu 52 orang $(17,3 \%)$, dan tingkat dua sebanyak 46 orang $(15,3 \%)$. Dari segi agama, sebanyak 231 orang $(77 \%)$ kristen protestan, 66 orang (22\%) Islam, 2 orang (7\%) Katholik, dan 1 orang (3\%) Budha.

Tabel. 2. Gambaran Lingkungan Sosial Subjek

\begin{tabular}{lcrc}
\hline \multicolumn{1}{c}{ Pertanyaan } & Jawaban & Frek & \% \\
\hline Apakah ada yang anda & Ya & 87 & 29 \\
kenal di lingkungan & Tidak & 213 & 71 \\
sekitar yang terinfeksi & & & \\
Covid-19? & & & \\
& & & \\
Apakah tempat tinggal & & 167 & 55,7 \\
anda memiliki risiko & Ya & 167 \\
terinfeksi Covid-19? & Tidak & 133 & 44,3 \\
\hline
\end{tabular}

Tabel 2 memperlihatkan gambaran lingkungan sosial subyek sebanyak 87 orang (29\%) mempunyai kerabat yang terinfeksi Covid19 sementara sebanyak 213 (71\%) yang tidak ada lingkungan yang terinfeksi Covid-19. Sebanyak 167 orang $(55,7 \%)$ tinggal di tempat yang berisiko terinfeksi Covid-19 dan 133 (44,3\%) tinggal di lingkungan yang tidak memiliki resiko terinfeksi Covid-19. 


\begin{tabular}{|c|c|c|c|}
\hline \multirow{3}{*}{$\begin{array}{l}\text { Tabel. 3. Distribusi } \\
\text { Instrumental, } \\
\text { Kesopanan, } \\
\text { Masyarakat }\end{array}$} & Frekuensi & \multicolumn{2}{|c|}{ Stigma } \\
\hline & Stigma Sin & bolis, & Stigma \\
\hline & dan & Pene & imaan \\
\hline Variabel & Kategori & Frek & $\%$ \\
\hline \multirow{2}{*}{ Stigma Instrumental } & Rendah & 99 & 33 \\
\hline & Tinggi & 201 & 67 \\
\hline \multirow{2}{*}{ Stigma Simbolis } & Rendah & 134 & 44,7 \\
\hline & Tinggi & 166 & 55,3 \\
\hline \multirow{2}{*}{ Stigma Kesopanan } & Rendah & 241 & 80,3 \\
\hline & Tinggi & 59 & 19,7 \\
\hline \multirow{2}{*}{ Penerimaan Masyarakat } & Baik & 225 & 75 \\
\hline & Buruk & 75 & 25 \\
\hline
\end{tabular}

Tabel 3 menunjukkan stigma instrumental masyarakat Kota Bandung mayoritas tinggi sebanyak 201 orang (67\%), stigma simbolis masyarakat sebagian besar tinggi sebanyak 166 orang $(55,3 \%)$, dan stigma kesopanan masyarakat mayoritas rendah sebanyak 241 orang (80,3\%). Penerimaan Masyarakat mayoritas baik sebanyak 225 orang $(75 \%)$ dan minoritas buruk sebanyak 75 orang (25\%).

Tabel. 4. Hubungan Stigma Covid-19 (Stigma Instrumental, Simbolis dan Kesopanan) dengan Penerimaan Masyarakat pada penderita Covid-19

\begin{tabular}{|c|c|c|c|c|c|c|c|}
\hline \multirow{3}{*}{ Stigma Covid-19 } & \multicolumn{7}{|c|}{ Penerimaan Masyarakat } \\
\hline & \multicolumn{2}{|c|}{ Baik } & \multicolumn{2}{|c|}{ Buruk } & \multicolumn{2}{|c|}{ Total } & \multirow[t]{2}{*}{ p-value } \\
\hline & $\mathbf{n}$ & $\%$ & $\mathbf{n}$ & $\%$ & $\mathbf{n}$ & $\%$ & \\
\hline \multicolumn{8}{|l|}{ Stigma Instrumental } \\
\hline Tinggi & 138 & 68,7 & 63 & 31,3 & 201 & 100 & 0,000 \\
\hline Rendah & 87 & 87,9 & 12 & 12,1 & 99 & 100 & \\
\hline \multicolumn{8}{|l|}{ Stigma Simbolitas } \\
\hline Tinggi & 107 & 64,5 & 59 & 35,5 & 166 & 100 & 0,000 \\
\hline Rendah & 118 & 88,1 & 16 & 11,9 & 134 & 100 & \\
\hline \multicolumn{8}{|l|}{ Stigma Kesopanan } \\
\hline Tinggi & 25 & 42,4 & 34 & 57,6 & 59 & 100 & 0,000 \\
\hline Rendah & 200 & 83 & 41 & 17 & 241 & 100 & \\
\hline
\end{tabular}

Tabel 4 menunjukkan hasil analisis hubungan antara penerimaan masyarakat dengan stigma instrumental, sebanyak 138 dari 201 $(68,7 \%)$ kategori penerimaan baik stigma instrumental tinggi, 87 dari 99 (87,9\%) kategori penerimaan baik stigma instrumental rendah, 63 dari $201(31,3 \%)$ kategori penerimaan buruk stigma instrumental tinggi, dan 12 dari 99 $(12,1 \%)$ kategori penerimaan buruk stigma instrumental rendah dengan $p$-value 0,000 yang diinterpretaskan signifikan. Hasil analisis hubungan antara penerimaan masyarakat dengan stigma simbolis, sebanyak 107 dari 166 (64,5\%) kategori penerimaan baik stigma simbolis tinggi, 118 dari $134(88,1 \%)$ kategori penerimaan baik stigma simbolis rendah, 59 dari $166(35,5 \%)$ kategori penerimaan buruk stigma simbolis tinggi, 16 dari 134 (11,9\%) kategori penerimaan buruk stigma simbolis rendah dengan $p$-value 0,000 yang diinterpretaskan signifikan. Hasil analisis hubungan antara penerimaan masyarakat dengan stigma kesopanan, sebanyak 25 dari 59 $(42,4 \%)$ penerimaan baik stigma kesopanan tinggi, 200 dari 241 (83\%) kategori penerimaan baik stigma kesopanan rendah, 34 dari 59 $(57,6 \%)$ kategori penerimaan buruk stigma kesopanan tinggi, dan 41 dari 241 (17\%) kategori penerimaan buruk stigma kesopanan rendah dengan $p$-value 0,000 yang diinterpretasikan signifikan.

\section{PEMBAHASAN}

Tabel 1 menunjukkan sebagian besar responden berjenis kelamin perempuan dengan presentase $67 \%$ dan mayoritas remaja akhir (1725 tahun) sebanyak 98,7\%. Menurut Berek dalam penelitiannya terhadap ODHA, didapatkan responden perempuan memiliki peluang lebih besar dari laki-laki untuk memberikan stigmatisasi (Berek \& Bubu, 2019). Hal ini sejalan dengan penelitian yang dilakukan Oktaviannoor, dkk terhadap penderita Covid-19 yang mengatakan bahwa perempuan cenderung lebih banyak melakukan stigma dibandingkan dengan laki-laki (Oktaviannoor, et al., 2020). Pendidikan responden sebagian besar berpendidikan tinggi sehingga dapat dikatakan pengetahuan masyarakat tentang penyakit Covid19 baik. Gheralyn mengatakan bahwa seseorang dengan pengetahuan yang baik mengenai Covid19 belum tentu tidak merasa cemas (Suwandi \& Malinti, 2020). Natalia, dkk mengatakan bahwa semakin tinggi pengetahuan maka semakin meningkat pula kesiapsiagaannya dalam menghadapi Covid-19 (Natalia, et al., 2020).

Tabel 2 menunjukkan sebanyak 55,7\% tinggal di lingkungan yang berisiko terinfeksi Covid-19 dan sebanyak 29\% memiliki kerabat yang terinfeksi virus corona. Tingginya angka kasus Covid-19 menimbulkan keresahan di 
masyarakat. Ditambah lagi ketidakpatuhan masyarakat dalam mematuhi protokol kesehatan belum dilakukan secara maksimal, seperti tidak memakai masker ke luar rumah, tidak menerapkan social distancing, serta tidak mencuci tangan dengan benar. Kurangnya pengetahuan tentang bahaya Covid-19, adanya kebutuhan hidup yang harus dipenuhi, serta tidak adanya sanksi merupakan beberapa kemungkinan penyebab masyarakat tidak patuh pada arahan pemerintah (Agustino, 2020).

Tabel 3 menunjukkan stigma instrumental (pengetahuan) masyarakat Kota Bandung mayoritas tinggi dengan persentase $67 \%$, dan stigma simbolis (sikap) masyarakat sebagian besar tinggi dengan presentase 55,3\%. Hal ini membuktikan masih ada masyarakat yang berpandangan bahwa penderita Covid-19 tidak layak tinggal berdekatan karena menderita penyakit yang menjijikkan. Tingginya angka penularan Covid-19 membuat masyarakat berusaha menghindar dari penderita Covid-19, baik orang terkonfirmasi positif, maupun eks pasien Covid-19 karena khawatir akan menularkan virus sehingga dirinya ditolak di dalam masyarakat (Humaedi, et al., 2020). Sikap masyarakat masih ada yang beranggapan bahwa penderita Covid-19 membawa pengaruh buruk, sehingga harus dijauhi dan tidak boleh hidup di tengah-tengah masyarakat.

Sementara itu, stigma kesopanan (tindakan) masyarakat kota Bandung mayoritas rendah dengan persentase $80,3 \%$. Penerimaan masyarakat terhadap penderita Covid-19 tergolong baik dengan persentase $75 \%$. Stigma dalam bentuk tindakan merupakan stigma yang paling memengaruhi penerimaan masyarakat karena berhubungan langsung dengan penderita Covid-19. Stigma dan diskriminasi sosial sangat berbahaya karena dapat menimbulkan konflik dan perpecahan dalam masyarakat dikarenakan rasa takut dan sikap over protective dalam menjaga diri (Widodo, 2020). Widodo melanjutkan, dalam situasi pandemik Covid-19 ini orang yang sakit tidak diberi bantuan melainkan didiskriminasi.

Tabel 4 menunjukkan adanya pengaruh stigma instrumental, stigma simbolis, dan stigma kesopanan pada penerimaan masyarakat terhadap penderita Covid-19. Semakin tinggi stigma instrumental dan stigma simbolis di masyarakat maka semakin buruk penerimaan masyarakat terhadap Covid-19. Namun, semakin tinggi stigma kesopanan maka semakin baik penerimaan masyarakat terhadap Covid-19. Orang yang menderita Covid-19 bukan disebabkan karena melakukan perbuatan aib, maka masyarakat seharusnya tidak menjauhi apalagi mengucilkan (Abudi, et al., 2020).

Stigmatisasi tidak hanya dirasakan oleh pasien Covid-19, tapi juga pada ODP (Orang Dalam Pengawasan), PDP (Pasien dalam Pengawasan), eks pasien Covid-19 bahkan tenaga kesehatan yang menangani pasien Covid-19. Beberapa tantangan yang terkait dengan stigma antara lain perasaan terisolasi, hilangnya interaksi secara langsung, kurangnya dukungan keluarga dan teman, serta enggan untuk meminta bantuan orang lain (Zolnikov \& Furio, 2020). Stigma pada tenaga kesehatan dapat berpengaruh pada performa kerja dan menurunkan kepuasan kerja (Ramaci, et al., 2020).

Upaya untuk melawan Covid-19 harus komprehensif, tidak hanya secara fisik, tapi juga jiwa dan psikososial masyarakat. Dampak pandemi Covid-19 pada kesehatan mental antara lain kesepian, kecemasan, stres, ketakutan, dan stigmatisasi. Salah satu cara untuk menghadapi kecemasan yaitu dengan menyeleksi informasi yang dengan baik (Vibriyanti, 2020). Hal ini sejalan dengan penelitian yang dilakukan pada mahasiswa Universitas Islam Bandung yang menunjukkan mayoritas mahasiswa menyaring informasi terlebih dahulu mengenai Covid-19 sehingga tidak menimbulkan kecemasan yang berlebihan pada diri sendiri dan orang lain (Azania \& Naan, 2021). Melakukan pemeriksaan pada informasi yang beredar dan mendidik masyarakat mengenai akibat dari mengonsumsi dan menyebarluaskan informasi yang salah merupakan tindakan yang dapat dilakukan untuk mengurangi diskriminasi (Chopra \& Arora, 2020).

Adanya stigmatisasi membuat masyarakat yang kemungkinan terkonfirmasi positif memilih untuk tidak memeriksakan diri daripada didiskriminasi, sehingga orang yang seharusnya isolasi mandiri malah bersikap sebaliknya yaitu tetap bergaul di lingkungan masyarakat. Komunikasi dua arah antara masyarakat dan pemerintah dapat menjadi salah satu penanganan stigma sehingga membantu masyarakat untuk mengetahui informasi yang faktual mengenai Covid-19 (Jelahut, 2020). Kampanye, promosi kesehatan, dan penyaringan berita hoax merupakan beberapa sarana yang bisa digunakan untuk meminimalisir stigma (Wanodya, 2020).

Komunikasi tidak hanya berupa informasi dalam bentuk kata-kata, tetapi dapat berupa ekspresi saling menguatkan yang dapat menumbuhkan rasa simpati dan empati serta menumbuhkan motivasi dalam dirinya dan orang lain (Muslih, 2020). Media sosial merupakan sarana yang paling tepat di era pandemi yang 
digunakan sebagai wadah untuk berbagi pengalaman dan saling memberi motivasi serta dukungan antar masyarakat dalam menghadapi pandemi Covid-19 (Sampurno, et al., 2020).

Penyuluhan terkait Covid-19 perlu dilakukan pada masyarakat mengenai pencegahan, tanda gejala, perkembangan penyakit, penularan, dan pemeriksaan dini jika ada gejala atau riwayat perjalanan ke luar kota. Penelitian yang dilakukan pada 1096 orang pengguna internet ditemukan bahwa mayoritas mempunyai sikap positif terhadap Covid-19 dan dikatakan pengetahuan berpengaruh pada sikap dan tindakan seseorang dalam upaya pencegahan Covid-19 (Syakurah \& Moudy, 2020).

Pendidikan kesehatan membantu individu dalam mengambil sikap yang bijaksana pada kesehatan dan kualitas hidup mereka, menambah pengetahuan sehingga dapat menerapkannya dalam kehidupan sehari-hari. Agar lebih mudah diingat oleh masyarakat, promosi kesehatan jiwa dapat dibuat dalam sistem jembatan keledai, seperti FEPiPeres (fisik relaks, emosi positif, pikiran positif, perilaku positif, relasi positif dan spiritual positif) untuk meningkatkan imunitas jiwa dan psikosisal, serta BAAR (breathe, access, action, reflect), 5M (mengetahui masalah, mengambil keputusan, merawat anggota keluarga, menciptakan lingkungan keluarga yang kondusif, menggunakan layanan kesehatan terdekat), 5B (belajar, beribadah, bermain, bercakap-cakap, berekreasi bersama keluarga), dan Go (gotong royong dan saling membantu) sebagai upaya pencegahan masalah kesehatan jiwa (Sumartyawati, et al., 2020).

Kontribusi yang bisa dilakukan sebagai individu yaitu meningkatkan rasa percaya pada layanan kesehatan, memberikan simpati dan empati kepada penderita Covid-19, serta mengikuti kebijakan yang telah ditetapkan pemerintah dalam menghadapi Covid-19. Beberapa diantaranya ialah, kebijakan berdiam diri di rumah (Stay at Home), pembatasan sosial (Social Distancing), pembatasan fisik (Physical Distancing), penggunaan masker, mencuci tangan, bekerja dan belajar di rumah (Work/Study from Home), dan kebijakan New Normal (Tuwu, 2020). Penelitian yang dilakukan di DKI Jakarta menunjukkan sebagian besar responden memiliki pengetahuan, sikap, dan keterampilan yang baik dalam upaya pencegahan Covid-19, namun kepatuhan masyarakat dalam mengikuti aturan protokol kesehatan dan Adaptasi Kebiasaan Baru (AKB) harus konsisten dilakukan agar tidak menambah kasus baru (Utami, et al., 2020).

Saat ini, propinsi Jawa Barat memiliki layanan kesehatan jiwa virtual dalam menghadapi pandemi Covid-19 dengan intervensi psikososial peer support dan art psychoterapy yang terutama ditujukan bagi mereka yang menjalani isolasi (Nugraha, 2020). Relaksasi merupakan salah satu teknik yang dapat digunakan untuk mengurangi stres dalam menjaga kesehatan mental (Aufar \& Raharjo, 2020). Terapi psikoedukasi pada keluarga juga dapat meningkatkan pengetahuan dalam merawat anggota keluarga yang mengalami masalah kesehatan mental, mengelola stres, dan memberdayakan komunitas untuk membantu keluarga (Sutinah, 2020). Aktivitas fisik secara rutin dapat memberikan dampak positif dalam proses fisiologis tubuh manusia, yaitu dapat menyalurkan oksigen dan aliran darah otak, dan memperbaiki penghantaran neurotransmiter kimia yang memberikan perasaan senang, meningkatkan kebugaran fisik dan kesehatan mental (Rusip, et al., 2020). Melalui sarana tersebut, diharapkan akan menurunkan tingkat kecemasan dan meningkatkan kekebalan tubuh sehingga dapat mengurangi angka kematian.

Menurut WHO dalam Social Stigma associated with Covid-19: A guide to preventing and addressing (2020) ada beberapa upaya yang dapat dilakukan untuk melawan stigmatisasi, diantaranya: 1) Menyebarkan fakta menggunakan bahasa sederhana, 2) Melibatkan influencer sosial untuk memperkuat pesan yang mengurangi stigma melalui media sosial yang dapat menjadi sarana dalam mengurangi stigma bila digunakan dengan baik, interaktif, aktif, dan kreatif (Frelians \& Perbawaningsih, 2020), 3) Perkuat suara orang yang pernah mengalami penyakit virus corona dan yang telah pulih dari Covid-19, 4) Menggunakan beragam komunitas yang terdampak dan bekerja sama untuk mencegah penyebaran Covid-19, 5) Mempromosikan konten seputar praktik pencegahan infeksi dasar, gejala Covid-19 dan kapan harus mencari perawatan kesehatan, 6) Tautkan sejumlah inisiatif mengatasi stigma dan stereotip untuk menciptakan gerakan dan lingkungan positif yang menunjukkan kepedulian dan empati.

\section{SIMPULAN}

Hasil penelitian menunjukkan sebanyak $29 \%$ responden memiliki kerabat yang terinfeksi Covid-19 dan sebanyak 55,7\% responden tinggal di lingkungan yang berisiko terinfeksi virus corona. Stigma intrumental dan simbolis masyarakat tergolong tinggi, sedangkan stigma kesopanan masyarakat cenderung rendah. Adanya hubungan yang signifikan antara stigma 
instrumental (pengetahuan), stigma simbolis (sikap), dan stigma kesopanan (tindakan) dengan penerimaan masyarakat terhadap penderita Covid-19. Semakin tinggi stigma instrumental dan stigma simbolis di masyarakat maka semakin buruk penerimaan masyarakat terhadap Covid-19. Namun, semakin tinggi stigma kesopanan maka

\section{DAFTAR PUSTAKA}

Abdillah, L. (2020). Stigma Terhadap Orang Positif COVID-19 (Stigma on Positive People COVID-19). Pandemik COVID-19: Antara Persoalan dan Refleksi Di Indonesia, Forthcoming. https://papers.ssrn.com/sol3/papers.cfm?ab stract_id=3582624

Abudi, R., Mokodompis, Y., \& Magulili, A. N. (2020). Stigma Terhadap Orang Positif Covid-19. Jambura Journal of Health Sciences and Research, 2(2), 77-84. https://doi.org/10.35971/jjhsr.v2i2.6012

Agustino, L. (2020). Analisis Kebijakan Penanganan Wabah Covid-19: Pengalaman Indonesia. Jurnal Borneo Administrator, $16(2)$, 253-270. https://doi.org/https://doi.org/10.24258/jba. v16i2.685

Aufar, A. F., \& Raharjo, S. T. (2020). Kegiatan relaksasi sebagai coping stress di masa pandemi COVID-19. Jurnal Kolaborasi Resolusi Konflik, 2(2), 157-163. http://journal.unpad.ac.id/jkrk/article/view/ 29126

Azania, D., \& Naan, N. (2021). Peran Spiritual Bagi Kesehatan Mental Mahasiswa di Tengah Pandemi Covid-19. HUMANISTIKA: Jurnal Keislaman, 7(1), 26-45.

https://doi.org/https://doi.org/10.36835/hu manistika.v7i1.384

Bafadhal, O. M., \& Santoso, A. D. (2020). Memetakan pesan hoaks berita COVID-19 di Indonesia lintas kategori, sumber, dan jenis disinformasi. Bricolage: Jurnal Magister Ilmu Komunikasi, 6(02), 235-249. https://doi.org/http://dx.doi.org/10.30813/b ricolage.v6i02.2148

Berek, P. A. L., \& Bubu, W. (2019). Hubungan Antara Umur, Jenis Kelamin, Pendidikan dan Pekerjaan dengan Stigmatisasi Terhadap Orang dengan Hiv/Aids di RSUD Mgr. Gabrielmanek, Svd Atambua. Jurnal Sahabat Keperawatan, 1(02), 36-43. http://jurnal.unimor.ac.id/JSK/article/view/2 semakin baik penerimaan masyarakat terhadap Covid-19.

Edukasi mengenai pencegahan dan penyebaran Covid-19 serta pentingnya kesehatan mental selama pandemi Covid-19 melalui pembagian leaflet atau sosial media perlu ditingkatkan agar masyarakat tidak salah informasi dan persepsi mengenai Covid-19.

\section{0}

Chopra, K. K., \& Arora, V. K. (2020). Covid-19 and social stigma: Role of scientific community. The Indian Journal of Tuberculosis.

https://www.ncbi.nlm.nih.gov/pmc/articles /PMC7362777/

CNN Indonesia. (2020). Pemerintah: Pasien Corona Tak Jujur Penyebab Dokter Meninggal. Cnnindonesia.Com. https://www.cnnindonesia.com/nasional/20 200506165207-20-500812/pemerintahpasien-corona-tak-jujur-penyebab-doktermeninggal

Fitria, L., \& Ifdil, I. (2020). Kecemasan remaja pada masa pandemi Covid-19. Jurnal EDUCATIO: Jurnal Pendidikan Indonesia, 6(1), 1-4. https://doi.org/http://dx.doi.org/10.29210/1 20202592

Frelians, P. P., \& Perbawaningsih, Y. (2020). Media Sosial Ruang Dayak dalam Mereduksi Stigma Kebudayaan Dayak. Jurnal Ilmu Komunikasi, 18(2), 181-193. https://doi.org/https://doi.org/10.31315/jik. v18i2.3230

Grover, S., Singh, P., Sahoo, S., \& Mehra, A. (2020). Stigma related to COVID-19 infection: Are the Health Care Workers stigmatizing their own colleagues? Asian Journal of Psychiatry. https://doi.org/https://dx.doi.org/10.1016\% 2Fj.ajp.2020.102381

Gultom, R. F. N., \& Tambunan, E. H. (2021). Pengalaman Mahasiswa Program Studi Pendidikan Ners Dalam Pembelajaran Daring Di Masa Pandemi Covid-19. Nursing Update: Jurnal Ilmiah Ilmu Keperawatan P-ISSN: 2085-5931 e-ISSN: 2623-2871, 12(1), 12-21. https://doi.org/https://doi.org/10.36089/nu. v12i1.311

Handayani, R. T., Kuntari, S., Darmayanti, A. T., Widiyanto, A., \& Atmojo, J. T. (2020). Faktor penyebab stres pada tenaga 
kesehatan dan masyarakat saat pandemi covid-19. Jurnal Keperawatan Jiwa, 8(3), 353-360.

https://www.researchgate.net/profile/Joko_ Atmojo/publication/347670731_Factors_C ausing_Stress_in_Health_and_Community _When_the_Covid-

19_Pandemic/links/5ff6e08fa6fdccdcb837 d94d/Factors-Causing-Stress-in-Healthand-Community-When-the-Covid-19Pandemic.pdf

Humaedi, S., Azizah, A., \& Taftazani, B. M. (2020). Upaya Peningkatan Keberfungsian Sosial Terhadap Eks Pasien Covid-19. Prosiding Penelitian Dan Pengabdian Kepada Masyarakat, 7(2), 371-376. https://doi.org/https://doi.org/10.24198/jpp m.v7i2.28873

Ilpaj, S. M., \& Nurwati, N. (2020). Analisis Pengaruh Tingkat Kematian Akibat Covid19 Terhadap Kesehatan Mental Masyarakat di Indonesia. Focus: Jurnal Pekerjaan Sosial, 3(1), 16-28. http://journal.unpad.ac.id/focus/article/view/ 28123

Jelahut, F. E. (2020). Peran Komunikasi Sebagai Mitigasi Stigmatisasi Covid 19. Jurnal Jurnalisa: Jurnal Jurusan Jurnalistik, 6(1). https://doi.org/https://doi.org/10.24252/jurnal isa.v6i1.13921

KEMKES RI. (2020). Infeksi Emerging. https://infeksiemerging.kemkes.go.id/

Liu, Y., Finch, B. K., Brenneke, S. G., Thomas, K., \& Le, P. D. (2020). Perceived discrimination and Mental Distress amid the COVID-19 pandemic: Evidence from the understanding America study. American Journal of Preventive Medicine, 59(4), 481-492. https://doi.org/https://doi.org/10.1016/j.am epre.2020.06.007

Livana, P. H., Setiawati, L., \& Sariti, I. (2020). Stigma and Community Behavior in Covid-19 Positive Patients. Jurnal Gawat Darurat, 2(2), 95-100. http://www.stikeskendal.ac.id/journal/inde x.php/JGD/article/view/952

Muslih, B. (2020). Urgensi komunikasi dalam menumbuhkan motivasi di era pandemi COVID-19. Jurnal Penelitian Manajemen Terapan (PENATARAN), 5(1), 57-65. https://journal.stieken.ac.id/index.php/pena taran/article/view/463

Muslim, M. (2020). Manajemen stress pada masa pandemi covid-19. ESENSI: Jurnal Manajemen Bisnis, 23(2), 192-201. https://ibn.e-
journal.id/index.php/ESENSI/article/view/205

Natalia, R. N., Malinti, E., \& Elon, Y. (2020). Kesiapsiagaan Remaja Dalam Menghadapi Wabah Covid-19. Jurnal Ilmiah Kesehatan Diagnosis, 15(2), 107-111. http://180.178.93.169/index.php/jikd/article/ view/203

Nugraha, A. (2020). Hadapi Pademi COVID-19, Jabar Punya Layanan Pendampingan Kesehatan Jiwa Virtual. https://www.liputan6.com/health/read/421 6289/hadapi-pademi-covid-19-jabarpunya-layanan-pendampingan-kesehatanjiwa-virtual

Oktaviannoor, H., Herawati, A., Hidayah, N., Martina, M., \& Hanafi, A. S. (2020). Pengetahuan dan stigma masyarakat terhadap pasien Covid-19 dan tenaga kesehatan di Kota Banjarmasin. Dinamika Kesehatan: Jurnal Kebidanan dan Keperawatan, 11(1), 98-109. http://ojs.dinamikakesehatan.unism.ac.id/

PUSICOV Kota Bandung. (2020). Update COVID-19. https://covid19.bandung.go.id/

Ramaci, T., Barattucci, M., Ledda, C., \& Rapisarda, V. (2020). Social Stigma during COVID-19 and its impact on HCWs outcomes. Sustainability, 12(9), 3834. https://doi.org/https://doi.org/10.3390/su12 093834

Ridlo, I. A. (2020). Pandemi COVID-19 dan Tantangan Kebijakan Kesehatan Mental di Indonesia. INSAN Jurnal Psikologi Dan Kesehatan Mental, 5(2), 162-171. https://doi.org/10.20473/jpkm.v5i22020.16 2-171

Rusip, G., Boy, E., Manihuruk, F. N., Sitorus, E. R. D., \& Ichwan, M. (2020). Edukasi Olah Raga Di Rumah Saja Sebagai Upaya Memelihara Kebugaran Fisik Dan Kesehatan Mental Di Masa Pandemi Covid 19 Bagi Mahasiswa Fakultas Kedokteran. Jurnal Implementa Husada, 1(2), 152-161. Sampurno, M. B. T., Kusumandyoko, T. C., \& Islam, M. A. (2020). Budaya media sosial, edukasi masyarakat, dan pandemi COVID19. SALAM: Jurnal Sosial Dan Budaya Syar-I, $\quad$ 7(5). https://doi.org/10.15408/sjsbs.v7i5.15210

Satuan Tugas Penanganan Covid-19. (2020). Ketahui: Stigma, efek samping COVID-19. KPCPN. https://covid19.go.id/edukasi/apayang-harus-kamu-ketahui-tentang-covid-19

Setyaningrum, W., \& Yanuarita, H. A. (2020). Pengaruh Covid-19 Terhadap Kesehatan Mental Masyarakat Di Kota Malang. JISIP (Jurnal Ilmu Sosial Dan Pendidikan), 4(4). 
http://ejournal.mandalanursa.org/index.php /JISIP/article/view/1580

Sumartyawati, N. M., Santosa, I. M. E., Sukardin, S., \& Marvia, E. (2020). Promosi Dukungan Kesehatan Jiwa dan Psikososial Pada Masyarakat di Wilayah Propinsi Nusa Tengga Barat. Jurnal Pengabdian Masyarakat Indonesia Maju, 1(03), 90-96. https://doi.org/10.33221/jpmim.v1i03.849

Sutinah, S. (2020). Pelaksanaan Terapi Psikoedukasi Keluarga Terhadap Beban Dan Dukungan Keluarga Akibat Pandemi Covid-19. Logista-Jurnal Ilmiah Pengabdian Kepada Masyarakat, 4(2), 177-185.

https://doi.org/10.25077/logista.4.2.177185.2020

Suwandi, G. R., \& Malinti, E. (2020). Hubungan Tingkat Pengetahuan Dengan Tingkat Kecemasan Terhadap Covid-19 Pada Remaja Di SMA Advent Balikpapan. Malahayati Nursing Journal, 2(4), 677-685. https://doi.org/https://doi.org/10.33024/manu ju.v2i4.2991

Syakurah, R. A., \& Moudy, J. (2020). Pengetahuan terkait usaha pencegahan Coronavirus Disease (COVID-19) di Indonesia. HIGEIA (Journal of Public Health Research and Development), 4(3-, 333-346.

https://doi.org/https://doi.org/10.15294/hig eia.v4i3.37844

Tuwu, D. (2020). Kebijakan Pemerintah Dalam Penanganan Pandemi Covid-19. Journal Publicuho, 3(2), 267. https://doi.org/10.35817/jpu.v3i2.12535

Utami, R. A., Mose, R. E., \& Martini, M. (2020). Pengetahuan, Sikap dan Keterampilan Masyarakat dalam Pencegahan COVID-19 di DKI Jakarta. Jurnal Kesehatan Holistic, 4(2),

68-77. https://doi.org/https://doi.org/10.33377/jkh.v $4 \mathrm{i} 2.85$

Vibriyanti, D. (2020). Kesehatan Mental Masyarakat: Mengelola Kecemasan di
Tengah Pandemi COVID-19. Jurnal Kependudukan Indonesia, 69-74. http://ejurnal.kependudukan.lipi.go.id/inde x.php/jki/article/view/550

Wang, C., Pan, R., Wan, X., Tan, Y., Xu, L., Ho, C. S., \& Ho, R. C. (2020). Immediate psychological responses and associated factors during the initial stage of the 2019 coronavirus disease (COVID-19) epidemic among the general population in China. International Journal of Environmental Research and Public Health, 17(5), 1729. https://doi.org/https://doi.org/10.3390/ijerp h17051729

Wanodya, K. S. (2020). Literature Review: Stigma Masyarakat Terhadap Covid-19. Preventia: The Indonesian Journal of Public Health, 5(2), 107-111. https://doi.org/http://dx.doi.org/10.17977/u m044v5i2p107-111

WHO. (2020). Social Stigma associated with COVID-19 A guide to preventing and addressing.

https://www.who.int/publications/m/item/a -guide-to-preventing-and-addressingsocial-stigma-associated-with-covid-19

Widodo, A. (2020). Pandemi dan Bentuk Diskriminasi Baru: Sebuah Kritik Terhadap Perilaku Masyarakat Dalam Menghadapi Wabah Covid-19. Jurnal Pendidikan Sosial Keberagaman, 7(2). https://doi.org/https://doi.org/10.29303/juri diksiam.v7i2.138

World Health Organization. (2020). Weekly Epidemiological Update on COVID-19 (15 November 2020). World Health Organization, 3 November, 1;4. https://www.who.int/docs/defaultsource/coronaviruse/situationreports/20201012-weekly-epi-update-9.pdf Zolnikov, T. R., \& Furio, F. (2020). Stigma on first responders during COVID-19. Stigma and Health. https://psycnet.apa.org/record/2020-69782001 